\title{
Economic and Socio-Cultural Relations between Indonesia and Taiwan: An Indonesian Perspective, 1990-2012
}

\author{
Luh Nyoman Ratih Wagiswari Kabinawa B Bina Nusantara University
}

\begin{abstract}
This paper analyzes the puzzle why did Indonesia maintain durable economic and sociocultural relations with Taiwan? In order to answer that question, this paper argues that due to the Indonesian people as promoter of ideas lead interactions with Taiwan, Indonesia is able to maintain its durable economic and socio-cultural relations with Taiwan despite under the absence of diplomatic relations. People-to-people interaction builds three kinds of interactions between Indonesia and Taiwan on the issue of economic and socio-cultural: unofficial interaction, semi-official interaction, and official interaction. This paper employs Indonesian perspective approach that stressed on the pattern of relations that stem from people-to-people interactions between Indonesia and Taiwan. Thus, the paper aims to fill the gap in the literature on Taiwan and Indonesia relations that mostly focus on analysis of economic diplomacy, interest (Leifer 2001; Ku 1995, Leong 1995, Lee 1990, Klintworth 1995, Rich 2009), shifting on international order (Ku;1998), and the PRC's factor on Indonesia and Taiwan relations (Ku 2002; Irawan 2006).
\end{abstract}

Keywords: Indonesian businessmen, Indonesian migrant workers, Indonesian students, economic and socio-cultural relations, people-to-people interactions

\section{Introduction}

Indonesia and Taiwan are two entities that do not have official diplomatic relations but maintain durable economic and socioculture relations. Though Indonesia adheres One China Policy principle, this country continues to nurture its relations with Taiwan in economic and socio-cultural aspects.

The most important event in Indonesia's relations with Taiwan occurred in 1989 when Taipei was allowed to rename its Chamber of Commerce in Jakarta from Chinese Chamber of Commerce into Taipei
Economic and Trade Office which gave politically meaningful status to Taiwan. Indonesia-Taiwan's harmonious relations did not stop there; in 1994 Taiwan launched a program called "Southward Policy" which aims to increase its investment and political relations with countries in Southeast Asia including Indonesia. Economic ties between Indonesia and Taiwan found within investment and trade activities while sociocultural ties lied within the existence of Indonesian migrant workers and Indonesian students in Taiwan.

Statistics on economic and socio-cultural relations between Indonesia and Taiwan 
showed improvement after the year of 1990s. In terms of economic investment, Taiwan was the eighth-largest foreign direct investor for Indonesia in 2010 (Center for Political Studies (P2P) LIPI 2011, p.6).

In terms of trading activity, Indonesia was Taiwan's eleventh-trading partner in 2010, being the thirteenth-largest export market and eleventh-largest supplier or imports (Center for Political Studies (P2P) LIPI 2011, p.6). On the context of sociocultural relations, Indonesian migrant worker is the first biggest population of foreign workers in Taiwan. In addition, Indonesian student is the third largest population of foreign students from Southeast Asia after Malaysia and Vietnam. relations with PRC in 1967, Indonesia has never recognized Taiwan.

Furthermore, Indonesia is one of the countries in Southeast Asia that strongly supported the principle of one-China Policy and signed strategic partnership relations with PRC in 2005. Thus, politically speaking, Indonesia does not have any incentive to improve its relations with Taiwan. Economically speaking, however, Indonesia and Taiwan are able to maintain strong economic and socio-cultural relations. Hence, this paper will explain the underlying reason that caused Indonesia and Taiwan are able to develop economic and socio-cultural interactions under the absence of diplomatic relations.

\section{Table 1. Statistics on Economic and Socio-Cultural Relations between Indonesia and} Taiwan 2010-2012

\begin{tabular}{|c|c|c|c|c|c|}
\hline Year & $\begin{array}{c}\text { Investment } \\
\text { (US\$ 1000) }\end{array}$ & $\begin{array}{c}\text { Export } \\
\text { (US\$ 1000) }\end{array}$ & $\begin{array}{c}\text { Import } \\
\text { (US\$ 1000) }\end{array}$ & $\begin{array}{c}\text { Indonesian } \\
\text { Migrant } \\
\text { Workers } \\
\text { (person) }\end{array}$ & $\begin{array}{c}\text { Indonesian } \\
\text { Students } \\
\text { (person) }\end{array}$ \\
\hline 2010 & 389 & 4.509 .630 & 6.020 .156 & 156.332 & 2,274 \\
\hline 2011 & 1.145 & 4.836 .625 & 7.428 .224 & 175.409 & 2,472 \\
\hline 2012 & 17.200 & 5.190 .198 & 7.324 .792 & 191.127 & 2,723 \\
\hline
\end{tabular}

Source: compilation from <http://www.moeaic.gov.tw/>; 〈http://web02.mof.gov.tw/> and Bureau of Foreign Trade: Trade Statistics, Republic of China (Taiwan), http://cus93.trade.gov.tw

The table clearly shows that each year statistics on economic and socio-cultural relations experience some improvements. However, durable economic and socioculture relations between Indonesia and Taiwan do not necessarily give positive impact toward their political-diplomatic relations. Indonesia since its independence in 1945 never recognized Taiwan as an independent state. Indonesia recognized the People's Republic of China (hereafter PRC) as the sole legitimate representative of Chinese government in 1950. Even after Indonesia suspended its diplomatic
Based on state-centric approach, a state that does not have political diplomatic relations with another state would be difficult to engage in formal governmental relations among each other. Nevertheless on the case of Indonesia and Taiwan, both nations are able to develop their economic and socio-culture relations even though official diplomatic ties are missing. Thus, this paper tries to answer the question: "Under the adherence of one-China policy principle and the absence of diplomatic relations with Taiwan, why did Indonesia 
maintain durable economic and sociocultural relations with Taiwan?"

This paper argues that due to the Indonesian people as promoter of ideas lead interactions with Taiwan, Indonesia is able to maintain its durable economic and sociocultural relations with Taiwan despite under the absence of diplomatic relations. People-to-people interaction builds three kinds of interactions between Indonesia and Taiwan on the issue of economic and sociocultural: unofficial interaction, semi-official interaction, and official interaction.

The paper employs Indonesian perspective approach to examine IndonesiaTaiwan relations. In addition, this paper will also examine case studies of economic and socio-culture issues. Economic issues involve aspect of investment, and trade while socio-culture issues include aspect of migrant workers and Indonesian students.

This paper consists of four sections. First is the introduction. Second section covers theoretical framework to set up the main indicators. Third section presents the discussion of main analysis. The last section is conclusion.

\section{Theoretical Framework}

The main analytical tool on this paper is people as promoters of new ideas (Snyder 2004, p.59) lead state's interaction with other states. The importance of people within the study of international relation has been acknowledged to promote state's relations with others. People-to-people interaction goes beyond the boundaries and sovereignty of the state. This part will examine the role of the people within state to state relations. Discussion will begin with conceptual approach from realist into constructivist's core ideas to explain their views on state to state relations. Later on, the conceptual approach will be narrow down into the proposed framework.
Realism approach treats state as the main unit analysis on international relations studies (Mingst 1996, p.70-78 and Snyder 2004, p. 59). State is the single and the main actor within the analysis of international relations phenomena. The idea of state is built from de facto and de jure idea. De facto consist of citizen, boundary and government, while de jure relates to the idea of sovereignty and recognition from other states ${ }^{1}$. The idea of sovereignty and recognition relies on the practice of acknowledgement of diplomatic relations among states. State practice government-togovernment contacts under the leverage of diplomatic relations. Thus, from realist point of view, interaction in the international order is filled by state to state interactions under the leverage of official diplomatic relations.

\section{Figure 1}

Official State to State Relations

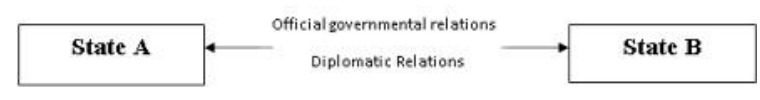

The above picture describes that state' A has official diplomatic relations with state B, thus both interact each other without any hesitation. Both states practice governmentto-government relations within various kinds of issues. Under official diplomatic relations, state is easier to conduct interactions with others. Nevertheless, not every state has official diplomatic relations with other states. Government-togovernment relations are unlikely occurred among state that lack of diplomatic relations. Therefore, state's interactions with others are not conducted under the official government level but through the existence

\footnotetext{
1 The idea of de facto and de jure is the basic term to define one entity as a state. Various discussion about the nature of the state can refer to Stephen D. Krasner, "Abiding Sovereignty", International Political Science Review, Jul., 2001, Vol. 22, No.3, pp. 231-233
} 
of third parties which are people ${ }^{2}$. People from one state interact with other state through their movement that goes beyond the state's boundaries and sovereignty. Together with the development of globalization, people could easily move from one state to another state.

People-to-people interactions under the absence of diplomatic relations among two states often called as informal relations. This term appear because the relations among states not conducted by the government but by the people. The picture below shows how interaction between states occurred through their people's interaction.

Figure 2

Non-Official State to State Approach

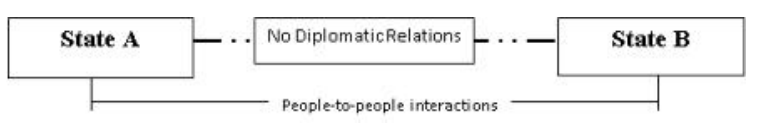

The above picture explains that state A does not have diplomatic relations with state $B$, thus both will be difficult to exercise official governmental exchanges. However, both countries still able to manage their relations due to the interactions that led by the people. People build the network and provide information for the states, thus, both states can manage their relations within various issues. On this case, state exercises its basic function as security and economic provider for the people.

To exemplify, people from state' A would like to do business in state B. Therefore, the people should move from state A into state B to run his/her business. In order to be able to enter state $B$, people from state A has to prepare some official

\footnotetext{
2 Third parties within state-to-state relations not only on the context of people but also on the context of other non-state actors such Multinational corporations, International Organizations or Non-governmental organizations. Due to the limitation of this thesis, however, this thesis only focuses to the role of people as third parties within Taiwan and Indonesia relations.
}

documents primarily resident or working visa. The issuance of visa is the matter of governmental issues, thus the government from state $\mathrm{A}$ has to cooperate with the government in state $B$ to issue visa for the people from state' A that would like to do business in state B. Hence, both governments are forced to work each other in order to fulfill the needs of issuing visa for the people.

From the above case, it explains two things. First, state as a security provider has to protect their people whose going overseas, without consideration whether the state has diplomatic relations or not with the other state. Thus the state has to work with other state in order to issue entry permit as a legal protection for their citizen when going overseas. Second, state as economic provider allows people from its state to do business overseas in order to fulfill economic interest of the people. Those two activities as security and economic provider cannot be conducted, unless the state also builds connection with designated state that has no diplomatic relations

The above mentioned explanations show how people from different state interacts each other and influenced state's relations. However, the explanation has not addressed the interest of the people that would like to enter the country that do not have official diplomatic relations with their state. The explanation has not answered the underlying reasons that endorse people from state's A willing to interact or to move with state B. Constructivist approach that focuses on the concept of ideas and values will be employed in order to explain the underlying reasons of people's migration. As mentioned before, realist approach treats state as the key actors on the study of international relations.

On the opposite side, constructivist builds their arguments based on the analysis of individual or promoters of new ideas (read: people) as the key actors in 
international relations (Snyder 2004, p.59 and Walt 1998, p.38).

Constructivist argues that interest is formed through the process of reciprocal interaction which constitute by the distribution of ideas. Interest is not given by order but rather than constructed through reciprocal interactions. It is said that interests being formed in the process of interaction rather than being formed prior to interaction (Baylis and Smith 1997, p.185).

Constructivist treats ideas and values as their main instruments to analyze the construction of interest (Snyder 2004, p.59). People act under the command of its ideas in which they will share it with others that created a formation of ideas. "Shared ideas making up norms, institutions, threatsystem, and so on - that constitute the meaning of the distribution of power, either by constituting state's perceptions of that distribution or by constituting their identities and interests" (Wendt 1999, p.104). Clear explanation about distribution of ideas as follows (Wendt 1999, p.104).

Figure 3

\section{Constructivist Approach on State to State Relations}

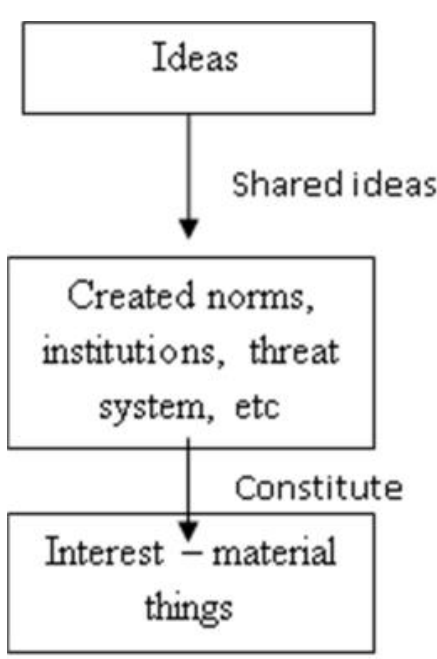

Above diagram explains the formation of interest that closely associated with material things such economic and/or security interest. Those interests are actually shape through distribution of ideas that promote by the people. Distribution of ideas mixed together with cultural-values making up norms and institution which at the end constitute identities and interests of the state. The process of interest formation also lurks by the culture (Wendt 1999, p.104). Thus interest are not given and shaped through material things, but rather from the process of distribution ideas or non-material elements.

In sum, analysis of ideas that shared by the people will be employed to examine the underlying reasons that caused people's migration under the absence of diplomatic relations among their government. Ideas are the reasons that endorse those people interact with another countries and societies. Wendt narrow down the concept of ideas into "knowledge" (Wendt 1999, p.104) that can be either private or shared knowledge. "Private knowledge consists of beliefs that individual actors hold that other do not"(Wendt 1999, p.104). This private knowledge refers to the domestic or ideological considerations that being the key determinant of people to frame and act toward the surrounding environment.

Meanwhile "shared knowledge or culture is the knowledge that becomes common knowledge among individuals" (Wendt 1999, p.141). Thus on this sense, socially shared knowledge or culture also play a role to influence actor's interactions. Private and shared knowledge are the foundations that influence people to interact with others.

Private and socially shared knowledge will be formed into an institution. Institution plays important role in bridging the governmental relations and providing network sharing and information. As argued by Wendt (1992), "institutions are fundamentally cognitive entities that do not exist apart from actor's ideas about how the world works". This institution embodied 
the distribution of ideas that socially shared by the people. Distribution of ideas together with the creation of institution constitutes the interest of the state that eventually influences the state's behavior to nurture its relations with the country that does not share diplomatic relations.

\section{Analytical Framework}

Drawing from the above mentioned theoretical explanations, Indonesia and Taiwan relations could be explained by looking at the people-to-people interactions that existed among their ties. Moreover, the concept of distribution of ideas - making up norms and institutions - constitute interest will also be employed to further analyzes the underlying reason that caused Indonesia is able to nurture its economic and socio-cultural relations with Taiwan. The clear explanation will be below will be addresses the underlying reasons that push or pull Indonesian businessmen, Indonesian migrant workers and Indonesian students come to Taiwan for their own purposes. Concept of ideas, institution and interest are the main analytical tools to examine the underlying reasons.

The term ideas consist of private knowledge and socially share knowledge. These two knowledge narrows down into several frameworks that caused Indonesian people interact with Taiwan. There are three main frameworks that help to explain the underlying reasons of people's migration: environmental, economic, and cultural frameworks. These frameworks will be used to examine factors that endorsed Indonesian businessmen; Indonesian migrant workers; and Indonesian students choose Taiwan as their destination for business, study and work.

Figure 4 Indonesian Diplomatic Relations with Taiwan

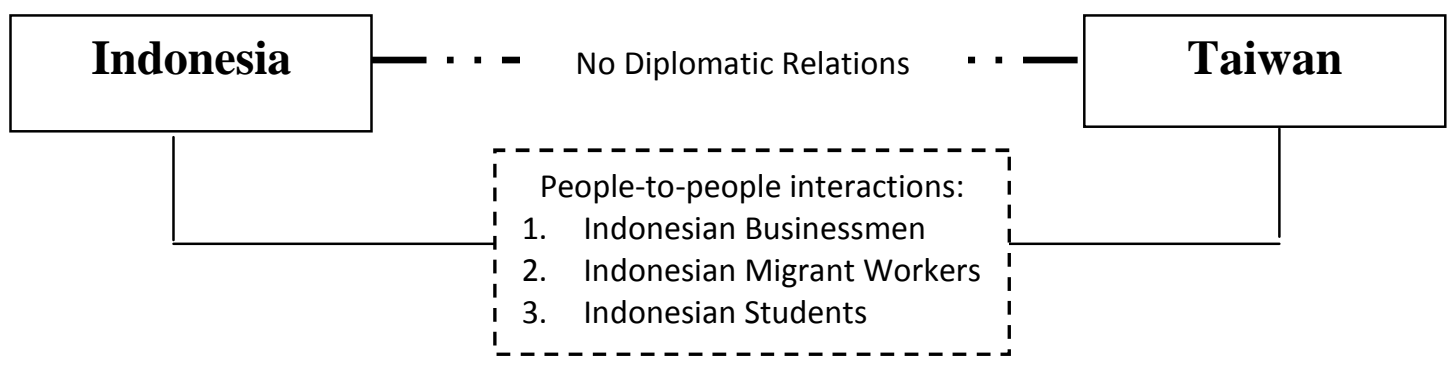

Above is the clear picture of Indonesia and Taiwan relations that built from peopleto-people interaction. Both countries can keep their contact due to the interactions that constructed by the people. A clear note must be made that people on the context of Indonesia and Taiwan relations are not limited to those above written, which this paper will be dealt with ${ }^{3}$. Further analysis

\footnotetext{
3 The term people within Indonesia and Taiwan relations are not limited to Indonesian businessmen, Indonesian migrant workers and Indonesian students. There are also other people such foreign spouse and/or Indonesian academic community. However, due to the limitation of this thesis
}

Above is the clear picture of Indonesia and Taiwan relations that built from peopleto-people interaction. Both countries can keep their contact due to the interactions that constructed by the people. A clear note must be made that people on the context of Indonesia and Taiwan relations are not limited to those above written, which this paper will be dealt with ${ }^{4}$. Further analysis that will analyze the economic and socio-cultural ties between Indonesia and Taiwan, hence the tool of analysis only consists of those former three categories of people.

4 The term people within Indonesia and Taiwan relations are not limited to Indonesian businessmen, Indonesian migrant 
will be addresses the underlying reasons that push or pull Indonesian businessmen, Indonesian migrant workers and Indonesian students come to Taiwan for their own purposes. Concept of ideas, institution and interest are the main analytical tools to examine the underlying reasons.

The term ideas consist of private knowledge and socially share knowledge. These two knowledge narrows down into several frameworks that caused Indonesian people interact with Taiwan. There are three main frameworks that help to explain the underlying reasons of people's migration: environmental, economic, and cultural frameworks. These frameworks will be used to examine factors that endorsed Indonesian businessmen; Indonesian migrant workers; and Indonesian students choose Taiwan as their destination for business, study and work.
Furthermore, ideas contribute to the making-up institution such Indonesian Business Association, Indonesian Student Association and Indonesian Migrant Workers Association. These institutions serve as independent agent that promotes Indonesia and Taiwan relations on the context of economic and socio-culture issues. These ideas and institution resulted in interest of Indonesia to maintain economic and socio-cultural relations with Taiwan. At the end, it will conclude that people-to-people interaction creates three kinds of interactions between Indonesia and Taiwan: unofficial interaction, semi-official interaction, and official interaction.

In order to get the valid results about the proposed indicators below, this paper conducts several interviews with relevant people to support the secondary data. This proposed framework will be discussed on the next section of this paper.

Figure 5. Proposed Framework Explaining Indonesia-Taiwan Relations

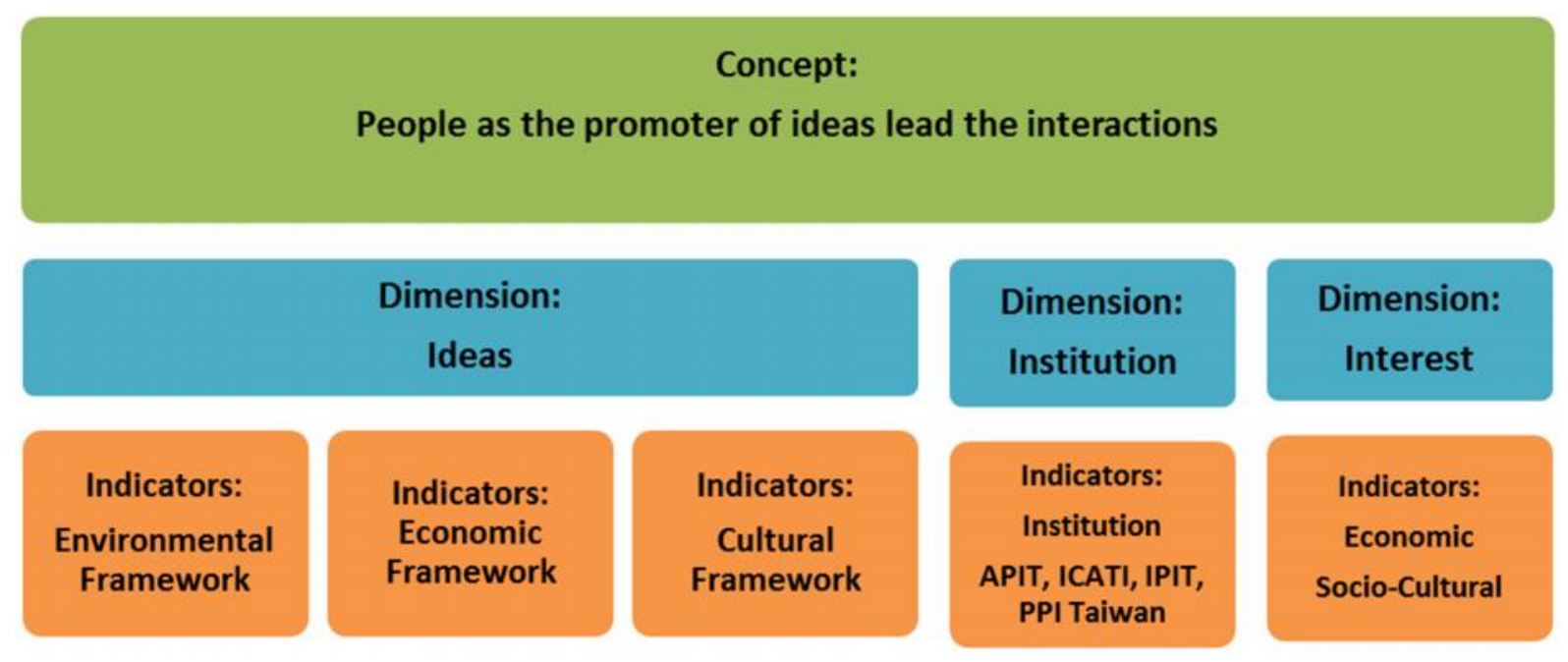

workers and Indonesian students. There are also other people such foreign spouse and/or Indonesian academic community. However, due to the limitation of this thesis that will analyze the economic and socio-cultural ties between Indonesia and Taiwan, hence the tool of analysis only consists of those former three categories of people. 


\section{Discussion}

This section covers the main analysis of the paper, ideas, institution and interests. To analyze ideas, institutions and interests within Indonesia and Taiwan relations, this section will be divided into three main parts. First part discusses three main frameworks of ideas that caused Indonesian people come to Taiwan for the purpose of business, working, and studying. Second part concerns on the making up institutions due to the shared ideas of the people. Third part talks about the resulted interests from the process of distribution of ideas and making up institutions.

\section{Framework of Ideas}

There are a lot of factors that endorse Indonesian students, Indonesian migrant workers, and Indonesian businessman to come to Taiwan. To explain factors related to the people's migration, this paper conducts interviews with three different groups of people. The first is representative from Indonesian businessmen who is being in charge as the head of Indonesian Employers Associations Store in Taiwan or Asosiasi Pengusaha Toko Indonesia di Taiwan (hereafter APIT) and representative from Indonesian Federation of Taiwan Alumni Associations or Ikatan Citra Alumni Taiwan Se-Indonesia (hereafter ICATI). The second is the representative from Indonesian migrant workers in Taiwan, represented by the head of Indonesian Migrant Workers Association in Taiwan or Ikatan Pekerja Indonesia Taiwan (hereafter IPIT). The last is representative from Indonesian students in Taiwan, represented by the head of Indonesian Student Association in Taiwan or Perhimpunan Pelajar Indonesia di Taiwan (hereafter PPI Taiwan). In addition, the interview was also conducted to some government officials that are relevant to the case studies.

Based on the results of interview, exist three main frameworks to explain the underlying reasons that influence student, migrant worker, and businessman choose Taiwan as their destination for study, work and run business. First is environmental framework which relates to the domestic and external situations that endorse people move to Taiwan. Second, economic framework relates to economic consideration of the people. Third is cultural framework that associate with cultural aspects that both develop in Taiwan and Indonesia.

Environmental Framework

Environmental framework relates to the domestic and external factors that endorse people move to Taiwan on the purpose of studying, working or doing business. Domestic factor is internal conditions within the state that force people to seek working, studying or business' opportunity overseas. Meanwhile, external factor is certain conditions in the host country that attract people to look for better prospect abroad. This factor associated with the comparative advantage which is earned by the designated country compare to others. Indonesian businessmen, Indonesian migrant workers and Indonesian students go for Taiwan due to domestic and external factors that stem within environmental framework.

Based on the interview conducted with the representative of Indonesian businessmen, migrant workers and students, this paper sum up several environmental frameworks that cause Indonesian people go to Taiwan for doing business, working and studying. 
Table 2 Summary of Environmental Framework

\begin{tabular}{|c|c|c|}
\hline \multirow{2}{*}{ Category of People } & \multicolumn{2}{|c|}{ Environmental Framework } \\
\hline & Domestic Factor & External Factor \\
\hline $\begin{array}{l}\text { Indonesian businessmen } \\
\text { (run business in Taiwan) }\end{array}$ & $\begin{array}{l}\text { Unfriendly experience of } \\
\text { socio-political conditions in } \\
\text { Indonesia toward ethnic } \\
\text { Chinese }\end{array}$ & $\begin{array}{l}\text { Huge population } \\
\text { Indonesian in Taiwan }\end{array}$ \\
\hline $\begin{array}{l}\text { Indonesian } \text { businessmen } \\
\text { (doing business with } \\
\text { Taiwan) }\end{array}$ & $\begin{array}{l}\text { Unfriendly experience of } \\
\text { socio-political conditions in } \\
\text { Indonesia toward ethnic } \\
\text { Chinese }\end{array}$ & ---- \\
\hline Indonesian migrant workers & $\begin{array}{l}\text { 1. Wants to gain working } \\
\text { experiences overseas } \\
\text { 2. Low degree of education } \\
\text { and skills }\end{array}$ & $\begin{array}{l}\text { Faster working placement } \\
\text { procedure and process in } \\
\text { Taiwan }\end{array}$ \\
\hline Indonesian students & $\begin{array}{l}\text { Demands to transform the } \\
\text { structure of the university in } \\
\text { Indonesia }\end{array}$ & $\begin{array}{l}\text { 1. Taiwan will be an } \\
\text { important country in the } \\
\text { future } \\
\text { 2. Taiwan offers } \\
\text { international } \\
\text { environment for study } \\
\text { 3. Taiwan has good quality } \\
\text { of research equipments } \\
\text { and professors } \\
\text { 4. Taiwan share similar } \\
\text { education system like in } \\
\text { the U.S. }\end{array}$ \\
\hline
\end{tabular}

Source: From the Author

\section{Economic Framework}

Economic framework relates to economic reasons that endorse people seeking opportunity abroad for business, working and studying. This framework focuses on maximum economic benefits that people could earn if they go to Taiwan rather than to other countries. Three categories of people consider economic framework as one of the important pushing factors that stimulate their willingness to look for better opportunity in Taiwan. Based on the interview conducted with the representative of Indonesian businessmen, migrant workers and students, this paper sum up several economic frameworks. (see Table 3).

\section{Cultural Framework}

The last framework is cultural framework that concern about the influence of culture within people-to-people interactions. As argued by Wendt, ideas consist of private and socially share knowledge. Socially share knowledge closely related to cultural matter that influences interactions. This framework will explain the impact of culture that eventually stimulates Indonesian people to connect with Taiwan. Culture could be related to language and society's beliefs and values. Summary of cultural framework listed in Table 4. 
Table 3 Summary of Economic Framework

\begin{tabular}{|l|l|}
\hline \multicolumn{1}{|c|}{ Category of People } & \multicolumn{1}{|c|}{ Economic Framework } \\
\hline $\begin{array}{l}\text { Indonesian businessmen (doing business in } \\
\text { Taiwan) }\end{array}$ & $\begin{array}{l}\text { 1. Business opportunity in Taiwan } \\
\text { 2. Small amount of capital to run business }\end{array}$ \\
\hline $\begin{array}{l}\text { Indonesian businessmen (doing business } \\
\text { with Taiwan/Taiwanese Business People) }\end{array}$ & Sizes of Taiwan's enterprises \\
\hline Indonesian migrant workers & $\begin{array}{l}\text { 1. High rate of unemployment } \\
\text { 2. Bigger amount of salary in Taiwan }\end{array}$ \\
\hline Indonesian students & $\begin{array}{l}\text { 1. Taiwan offers sufficient amount of } \\
\text { scholarship } \\
\text { Taiwan offers reasonable cost of tuition } \\
\text { fees and living }\end{array}$ \\
\hline
\end{tabular}

Source: from the Author

Table 4 Summary of Cultural Framework

\begin{tabular}{|l|l|}
\hline \multicolumn{1}{|c|}{ Category of People } & \multicolumn{1}{|c|}{ Cultural Framework } \\
\hline $\begin{array}{l}\text { Indonesian businessmen (doing business in } \\
\text { Taiwan) }\end{array}$ & Mandarin as means of communication \\
\hline $\begin{array}{l}\text { Indonesian businessmen (doing business } \\
\text { with Taiwan) }\end{array}$ & $\begin{array}{l}\text { 1. Mandarin as means of communication } \\
\text { 2. Sense of ownership to the motherland in } \\
\text { China } \\
\text { 3. Familiar and experienced with } \\
\text { Taiwanese culture and ethic }\end{array}$ \\
\hline Indonesian migrant workers & $\begin{array}{l}\text { 1. Beliefs of filial piety that create high } \\
\text { demand of migrant workers }\end{array}$ \\
\hline Indonesian students & $\begin{array}{l}\text { Taiwan offers Mandarin's environment for } \\
\text { study }\end{array}$ \\
\hline
\end{tabular}

Source: from the Author

In sum, Indonesian businessmen, migrant workers and students come to Taiwan due to several ideas that narrow down into three main frameworks: environmental, economic, and cultural framework. These ideas or private knowledge will be very "thin" idea unless it mixes with the shared knowledge or culture (Wendt 1999, p.141). Thus, Ideas combines with the influence of culture will endorse people from one state to interact with others. These frameworks successfully explain the underlying reasons that cause Indonesian people look for Taiwan in the purpose of business, working and studying.

\section{Creation of Institution and Norms}

Drawn from the previous explanations, shared ideas either private or shared knowledge making up norms and institutions. The previous sections, already addressed the shared ideas of doing business in and with Taiwan, working, and studying in Taiwan. This section will examine how shared ideas contribute to the creation of institutions and norms within Indonesia and Taiwan. Institutions and norms relate to the existence of association that built by those three types of people. 
Therefore, this part will discuss the existence of institutions such Asosiasi Pengusaha Toko Indonesia di Taiwan (hereafter APIT), Ikatan Citra Alumni Taiwan SeIndonesia (hereafter ICATI), Ikatan Pekerja Indonesia Taiwan (hereafter IPIT) and Perhimpunan Pelajar Indonesia di Taiwan (hereafter PPI Taiwan). As argued by Wendt, institution exists due to share ideas of the people. Hence these institutions and norms are existed due to the consequence of private and shared knowledge or ideas. Institution plays important role in bridging the governmental relations and providing network sharing and information. Furthermore, these institutions serve their role as independent agent either independent economic agent and/or independent socio-cultural agent ${ }^{5}$. They have valuable strategic and bargaining positions on the context of strengthening Indonesian and Taiwan relations particularly on economic and socio-cultural issues.

In order to address the role of those institutions, this paper also conducts indepth interview analysis with the head of the representative of the Institutions. The result of the interview is showed in the Figure 6.

Asosiasi Pengusaha Toko Indonesia di Taiwan or APIT was established in 2008 with the main aims to coordinate business activities among Indonesian businessmen in Taiwan. Due to a huge interactions and populations of Indonesian stores in Taiwan, it needs an association to coordinate business activities to reduce the unfair business competition and stigma among the Indonesian businessmen (Head of Asosiasi

5I used the term independent agent for those institutions that help to promote Indonesia and Taiwan relations. The term independent agent means this institution promotes economic and socio-cultural relations between Indonesia and Taiwan but has independent status because their movement not based on the order of the government. The term will be used for those institution throughout this section
Pengusaha Toko Indonesia di Taiwan (APIT) 2013). So far APIT has 70 members that spread-out from the north into the south of Taiwan. APIT serve as independent social agent or "social ambassadors" because this institution has two main social programs: provide social assistances programs and passport services for the migrant workers (Head of Asosiasi Pengusaha Toko Indonesia di Taiwan (APIT) 2013).

Social assistances program is APIT's activity related to the financial action's given toward Indonesian migrant workers that have serious illnesses or get accident during the working time, but not affordable for the medication cost. The other program is providing passport services for the Indonesian migrant workers with reasonable prices. The original price to apply for new passport is NTD 750, however, due to several technical reasons such taking photo, fingerprint process, and interview, the migrant workers should spend around NTD 3,000 - 5000 for those who live in Taipei and NTD 5,000 - 10,000 for those who live in Kaohsiung (Head of Asosiasi Pengusaha Toko Indonesia di Taiwan (APIT) 2013). Thus, to reduce the cost of passport services, APIT works together with the IETO to provide passport services program with reasonable prices for the migrant workers (Head of Asosiasi Pengusaha Toko Indonesia di Taiwan (APIT) 2013). Hence, those migrant workers that require to extent their passport only need to go to APIT branch offices and give the mandate of passport to APIT. On this case, APIT also works as "social ambassadors" both for the Indonesian government and migrant workers. Furthermore, APIT also serve as independent economic agent through their business activities that contribute to the foreign remittance and tax for both Indonesia and Taiwan.

The second institution is ICATI. ICATI serves as independent cultural agent and independent economic agent that help to 
promote the economic and socio-cultural relations between Indonesia and Taiwan. On the context of independent cultural agent, ICATI conducts several programs such as hosted the Calligraphy Class which sponsored by Taipei Economic and Trade Office (hereafter TETO), provide assistances for Indonesian students that willing to continue their study in Taiwan, and promoter for the sister-city MOU between Singkawang, West Kalimantan with Taoyuan, Taiwan (ICATI Website 2013). ICATI activities always include the representative from TETO, thus ICATI build socio-cultural network with Taiwan through its representative office in Jakarta.

On the context of independent economic agent, ICATI served as a bridge for the Taiwanese Investors that going to invest in Indonesia (President of Indonesian Federation of Taiwan Alumni Association (ICATI in Bahasa) 2013). They create a bridge that has two main functions. First, ICATI built economic cooperation and network with Taiwan Business Club in 2008 and TETO Economic Division (President of Indonesian Federation of Taiwan Alumni Association (ICATI in Bahasa) 2013). These cooperation and network help to promote investment activity in Indonesia which is done by Taiwanese Business People. Second, ICATI also help to reduce language barrier that occurred between the Taiwanese investors and local partners in Indonesia. ICATI's members are graduated from Taiwan universities thus made them able to speak fluent Mandarin.

The third institution that also builds from the shared ideas of the people is Indonesian Migrant Workers Association in Taiwan or Ikatan Pekerja Indonesia Taiwan (hereafter IPIT). IPIT was established in 2008 as a response toward a bunch of violations against Indonesian migrant workers from the Taiwanese employer (Head of Ikatan Pekerja Indonesia Taiwan (IPIT) 2013).There are two categories of violation against the migrant workers: labor case violations and non-labor case violations (Head of Labor Department, Indonesian Economic and Trade Office (IETO) in Taipei 2013). Labor case violations relate to the problem of payment of salary, taxes and savings procedure with agents; meanwhile non-labor cases include the case of sexual harassment. In order to reduce the burden and raise solidarity among migrant workers against the violation, the Indonesian migrant workers formed IPIT.

IPIT also serves as an independent social agent that concern over the capacity building activity for the migrant workers. This institution has two main activities that help to build the capacity knowledge of the Indonesian migrant workers (Head of Labor Department, Indonesian Economic and Trade Office (IETO) in Taipei 2013). First, provide training such language enrichment program (Mandarin and English), music, and computer learning. Second, hold a discussion forum to search a solution for the Indonesian migrant workers that have to deal with some violation problems. In order to solve the violation problems, IPIT also work together with IETO office. From these two programs, IPIT play as independent social agents which help to solve the problem of migrant workers by building a linkage between Indonesian representative government and Taiwan's nongovernmental organization that focus on migrant workers issues.

The last institution is PPI Taiwan. PPI Taiwan was established on May 2nd, 2010 with four main aims: to strengthen the sense of brotherhood and unity among Indonesian students in Taiwan, to actualize academic community and environment among Indonesian students, to perform actively as an Indonesian cultural ambassador abroad, and to strengthen international cooperation and partnership within people and society both toward Taiwan, Indonesia and international 
community (the Statute of Indonesian Student Association in Taiwan, Article 7). The member of PPI Taiwan comprises all Indonesian students in Taiwan, hence, PPI Taiwan actually has a lot of network from its member because it includes Indonesian students all over Taiwan that also have various professional background or knowledge (Head of Perhimpunan Pelajar Indonesia di Taiwan (PPI Taiwan) 2013).

PPI Taiwan has several main programs to fulfill its function as independent sociocultural agent. First, PPI Taiwan routinely conducts capacity building activity with migrant workers. This capacity building activity always includes the Director of Labor Department IETO as the guest speaker with various topics such immigration, employment, consular and how to solve problems related to the migrant workers.

In addition, the capacity building also involves health counseling on the issues of HIV/AIDS. This kind of capacity building not only takes place in northern Taiwan but also held in Central or Southern Taiwan.
Second, PPI Taiwan also actively organized focus group discussion, seminar or public discussion that discusses various academic topics and invites professional guest speakers. This activity aims to increase the capacity building of Indonesian students in Taiwan.

Third, PPI Taiwan also involve within governmental research project facilitated by IETO. Fourth, PPI Taiwan always participates and supports Indonesian Culture Exhibition or Festival which held by Indonesian students to introduce Indonesian culture toward Taiwanese society. This activity can create mutual understanding between Indonesia and Taiwan both in present and future time.

The last, PPI Taiwan provide information and networking center for Indonesian students that are going to study in Taiwan. In this way, PPI Taiwan also helps Taiwan to improve the number of international students from Indonesia that would like to earn degree in Taiwan. In sum, the emergence of PPI Taiwan helps to promote people-to-people interactions between Indonesia and Taiwan under the absence of diplomatic relations.

Figure 6 The Role of Institutions in Indonesia-Taiwan Relations
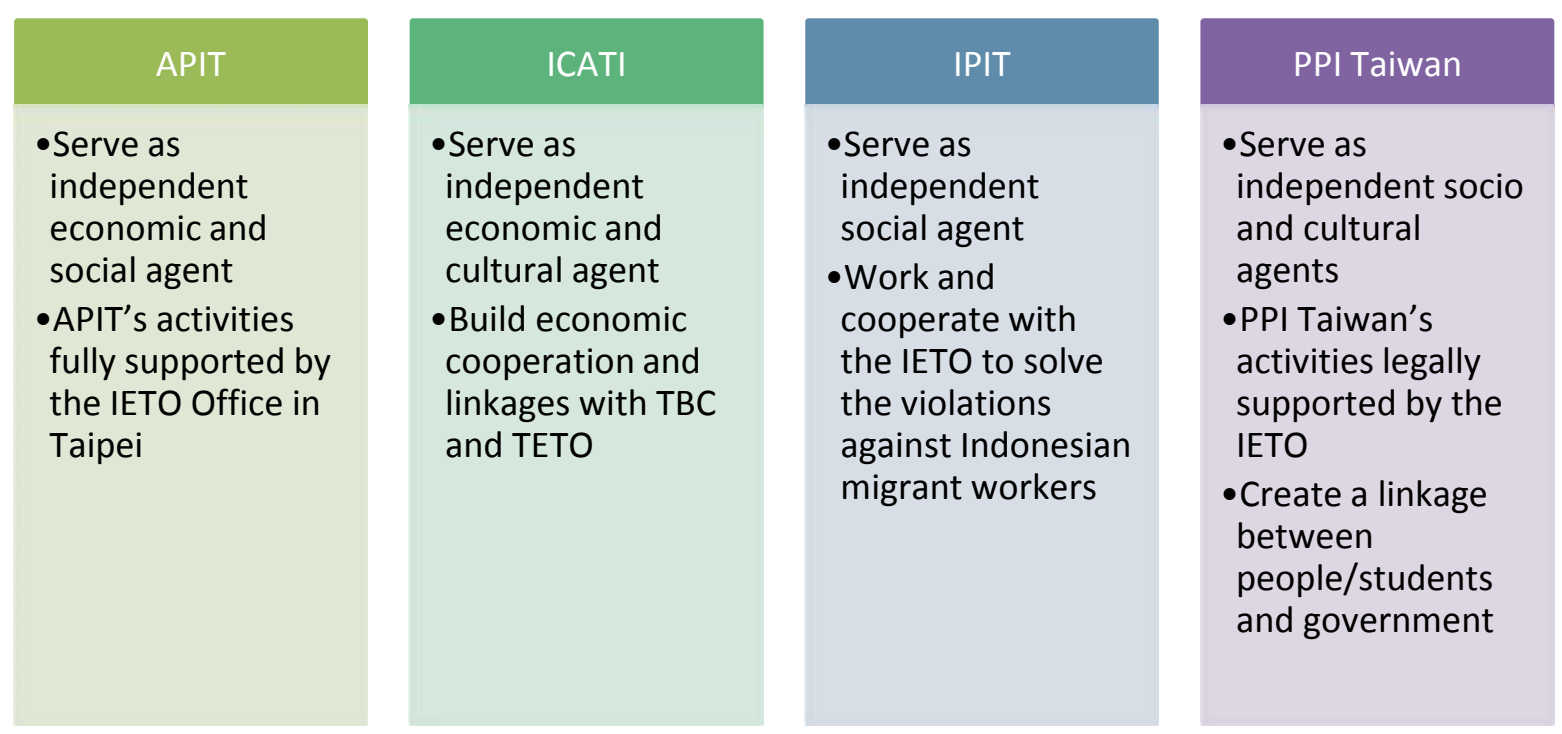

Source: from the Author 
Overall, similar distribution of ideas about coming to Taiwan for the purpose of business, working, and studying contribute to the making up institutions. These institutions are formed under the sense of unity and brotherhood to help each other and to improve interaction within businessmen, migrant workers and students.

Furthermore, those four institutions work independently as economic and sociocultural agent; hence they can promote Indonesia and Taiwan relations without any fear of political interventions or pressure that could occur from any sides as a consequent of one-China policy that hold by Indonesian government (Head of Perhimpunan Pelajar Indonesia di Taiwan (PPI Taiwan) 2013). The existence of these institutions also provides an incentive for the Indonesian government to maintain its economic and socio-cultural relations with Taiwan. It proves through several official governmental exchanges that occurred through the incentives that stem from the people-to-people interactions.

\section{Economic and Socio-Cultural Interests between Indonesia and Taiwan}

According to Wendt (1999) shared ideas both private knowledge and socially shared knowledge making up norms and institutions that constitute state's identities and interests. The two previous sections of this article have already discussed about shared ideas and making up institutions between Indonesia and Taiwan. Hence, this section will analyze the third indicators of independent variable about economic and socio-cultural interest between Indonesia and Taiwan. These interests stem due to the shared ideas and creation of institutions by the Indonesian businessmen, Indonesian migrant workers and Indonesian students. Furthermore, these interests cause three levels of interactions between Indonesia and Taiwan that stem from people-to-people interactions.

The first is unofficial interaction that purely consists of only economic and sociocultural interactions that do not include formal governmental exchanges. The second is semi-official interaction that has average political implications. This level includes official governmental exchanges either from Taiwan or Indonesia. The last is official interaction that comprises of official government-to-government exchanges between Indonesia and Taiwan. This level gives highest political implications because it contains official government exchanges. In order to explain economic and sociocultural interest between Indonesia and Taiwan as well as the level of interactions this section will be divided into two parts, economic interests and socio-cultural interest.

\section{Economic Interests}

Economic interests of Indonesia toward Taiwan stem from people-to-people interactions that build from Indonesian businessmen together with Taiwanese investors. Indonesia that adhere one-China policy principle will be difficult to define and conduct its economic relations with Taiwan. However, due to Indonesian businessmen that collaborate with Taiwanese investors created massive economic interactions and networks, both countries are able to maintain its economic relations. There are three levels of economic interactions that appear to measure economic interests between Indonesian and Taiwan.

The first is unofficial economic interaction. On this level, interactions between Indonesia and Taiwan purely built through economic activities such trade and investment conducted either by Indonesian businessmen or Taiwanese business people. There are no official governmental 
exchanges between the two countries on this level of interactions. Economic activities on this level include but not limited to foreign direct investment from Taiwan to Indonesia, recruitment of Indonesian workers to work at Taiwanese factories built in Indonesia, trade through private firms, business or trade conference conducted by private sector, seminar and/or fairs that not include government officials, and other activities that only rely on purely economic interactions. So, the final outcome from those activities would be to fulfill the economic interest between Indonesia and Taiwan.

The second level is semi-official economic interactions that comprise economic exchanges between officials either from Indonesia or Taiwan with Indonesian businessmen and/or Taiwan business people.
Economic activities within this level were mostly conducted by independent economic agents such as ICATI and Taiwan Business Club that also invite governmental officials whether from Indonesian or Taiwan. From 1990 until 2012, there have been 6 semi-officials economic interactions between Indonesia and Taiwan.

The table 6 shows semi-official economic exchanges between Indonesia and Taiwan. These activities mostly run by Taiwan business people that work together with Indonesian businessmen, which also involved government officials either from Indonesia or Taiwan. The outcome not only contributes to economic benefits but also average political implications because involving some of government officials.

Table 6. Semi-Officials Economic Exchanges between Indonesia and Taiwan, 1990-

2012

\begin{tabular}{|l|l|l|}
\hline \multicolumn{1}{|c|}{ Date } & \multicolumn{1}{|c|}{$\begin{array}{c}\text { Semi-Officials Economic } \\
\text { Exchanges }\end{array}$} & \multicolumn{1}{c|}{ Main Aims } \\
\hline May 1991 & $\begin{array}{l}\text { Jakarta-Taipei School was } \\
\text { established }\end{array}$ & $\begin{array}{l}\text { To fulfill the needs of better education of } \\
\text { Taiwanese Businessmen's children that } \\
\text { reside in Jakarta }\end{array}$ \\
\hline July 1995 & $\begin{array}{l}\text { Surabaya-Taipei International } \\
\text { School was established }\end{array}$ & $\begin{array}{l}\text { To fulfill the needs of better education of } \\
\text { Taiwanese Businessmen's children that } \\
\text { reside in Surabaya }\end{array}$ \\
\hline Ju00s & $\begin{array}{l}\text { Taiwan reduce the amount of } \\
\text { capital to invest or run business in } \\
\text { Taiwan }\end{array}$ & $\begin{array}{l}\text { To attract more investment or business } \\
\text { activity from foreign countries including } \\
\text { Indonesia }\end{array}$ \\
\hline $\begin{array}{l}\text { September } \\
\text { 2011 }\end{array}$ & $\begin{array}{l}\text { Day organized by TAITRA was } \\
\text { held in Taipei } \\
\text { MOEA Taiwan launched a } \\
\text { business tour to Indonesia for the } \\
\text { investment and business activities }\end{array}$ & $\begin{array}{l}\text { To discuss and to improve future } \\
\text { economic relations between Indonesia } \\
\text { and Taiwan } \\
\text { activities of Taiwanese investors in } \\
\text { Indonesia }\end{array}$ \\
\hline July 2012 & $\begin{array}{l}\text { Hon Hai Chairman (Foxconn) } \\
\text { Terry Gou, visited Indonesia as the } \\
\text { invitation from the Indonesian } \\
\text { government }\end{array}$ & $\begin{array}{l}\text { To survey the market for investment in } \\
\text { Indonesia }\end{array}$ \\
\hline
\end{tabular}

Source: Data collected randomly from reliable sources such Governmental Official Webpage and Indonesia and Taiwan Newspaper 
The third level is official economic interaction. This level of interaction includes official economic exchanges that involve high-level of government officials such as Minister or Deputy Representative between Indonesia and Taiwan.
Official economic exchanges embrace two main activities: sign MOU to strengthen economic relations and governmental visit or exchange.

Table 7 Officials Economic Exchanges between Indonesia and Taiwan, 1990-2012

\begin{tabular}{|c|c|c|}
\hline Date & changes & iims \\
\hline 1990 & $\begin{array}{l}\text { onesia and Taiwan signed Bilateral } \\
\text { estment Protection Agreement }\end{array}$ & $\begin{array}{l}\text { To give protection and non-discrimination } \\
\text { status for foreign investment in Indonesia, } \\
\text { including Taiwanese investment }\end{array}$ \\
\hline $\begin{array}{l}\text { January } \\
1995\end{array}$ & $\begin{array}{l}\text { The Indonesian Chamber of Commerce } \\
\text { in Taipei was renamed into the } \\
\text { Indonesian Economic and Trade Office } \\
\text { (IETO) in Taipei }\end{array}$ & $\begin{array}{l}\text { To further strengthen the economic and trade } \\
\text { activity between Indonesia and Taiwan. This } \\
\text { ideas stem due to the increasing number of } \\
\text { investment and trade activities that stem from } \\
\text { people-to-people interactions }\end{array}$ \\
\hline 1995 & $\begin{array}{l}\text { Indonesia and Taiwan signed } \\
\text { Agreement for the avoidance of double } \\
\text { taxation and the prevention of fiscal } \\
\text { evasion with respect to taxes on income }\end{array}$ & $\begin{array}{l}\text { To regulate the taxation system in order to } \\
\text { avoid double taxation that could stem from } \\
\text { economic activities between Indonesia and } \\
\text { Taiwan }\end{array}$ \\
\hline July 2010 & $\begin{array}{l}\text { Indonesia's Minister for Maritime } \\
\text { Affairs and Fisheries visited Taiwan to } \\
\text { propose joint development in Morotai } \\
\text { Island to President Ma Ying Jeou }\end{array}$ & $\begin{array}{l}\text { To develop Morotai Island and to diversify } \\
\text { Taiwanese investment in Indonesia. Taiwanese } \\
\text { investment in Indonesia mostly concentrated } \\
\text { in Java Island under the area of Jababeka } \\
\text { Group }\end{array}$ \\
\hline $\begin{array}{l}\text { August } \\
2010\end{array}$ & $\begin{array}{l}\text { The Chairman of Indonesia Investment } \\
\text { Coordination Board (BKPM), Gita } \\
\text { Wirjawan, visited Taipei and Kaohsiung } \\
\text { for investment purpose }\end{array}$ & $\begin{array}{l}\text { To increase investment activities between } \\
\text { Taiwanese investors and Indonesian } \\
\text { businessmen }\end{array}$ \\
\hline $\begin{array}{l}\text { September- } \\
\text { October } \\
2010\end{array}$ & $\begin{array}{l}\text { Taiwan Ministry of Economic Affairs, } \\
\text { Dr. Yen-Shiang Shih made a visit to } \\
\text { Jakarta together with Taiwanese } \\
\text { business delegation }\end{array}$ & $\begin{array}{l}\text { To make a courtesy call on BKPM and to } \\
\text { visit Jababeka and Lippo Cikarang } \\
\text { Export Processing Zone for assessment } \\
\text { of investment. }\end{array}$ \\
\hline $\mathrm{Ma}$ & $\begin{array}{l}\text { Indonesian Minister of Marine Affairs } \\
\text { and Fisheries visited Taiwan to } \\
\text { participate in the "Forum for } \\
\text { Cooperation in Morotai" and advocate } \\
\text { bilateral cooperation toward } \\
\text { development in the island }\end{array}$ & $\begin{array}{l}\text { the further implementation of jont } \\
\text { nt over Morotai Project }\end{array}$ \\
\hline May 20 & $\begin{array}{llll}\begin{array}{l}\text { Indonesian } \\
\text { Taiwan }\end{array} & \text { Trade } & \text { Minister visited } \\
\end{array}$ & $\begin{array}{l}\text { To discuss the investment possibility of } \\
\text { Foxconn }\end{array}$ \\
\hline $\begin{array}{l}\text { December } \\
2012\end{array}$ & $\begin{array}{l}\text { Taiwan-Indonesia signed memorandum } \\
\text { of understanding on a plan to jointly } \\
\text { develop Morotai Island }\end{array}$ & $\begin{array}{l}\text { To develop Morotai Island through investment } \\
\text { activities that conducted by Taiwanese } \\
\text { investors and local partner of Indonesian } \\
\text { businessmen }\end{array}$ \\
\hline
\end{tabular}

Source: Data collected randomly from reliable sources such Governmental Official Webpage and Indonesia and Taiwan Newspaper 
From 1990 until 2012, there have been 9 official economic interactions in terms of trade and investment that conducted by both Indonesia and Taiwan government. These official economic contact, mainly are driven to accommodate the investment and trade interests that stem from people-topeople interactions. The official interactions can be in the Table 7 .

Based on the table 7 above, it shows that official governmental interactions between Indonesia and Taiwan were mainly formed through the interests of Taiwanese investment and Indonesian businessmen that would like to further increase investment and trade activities. Economic activities that conducted through Indonesian businessmen and Taiwan business people, give political implications toward government affairs. Their activities force both governments to work together though under the absence of diplomatic relations.

The government works as economic facilitator and economic provider for the massive interactions that emerge from people-to-people interactions. ${ }^{6}$ The term economic facilitator and provider refer to some activities such issuing visa for those who want to run business both in Indonesia and Taiwan, formulating regulations to ensure investment activities, searching local partners for Taiwanese investments, providing information about trade and investment activities, signing MOU to lure investment and trade relations. ${ }^{7}$ In sum, Indonesia's economic interest toward Taiwan stems and shapes from the interactions that built by Indonesian businessmen and Taiwanese investors.

\footnotetext{
6 This statement also supported by Indonesian representative officials in IETO based on the interview with the Head of Industry Department, Indonesian Economic and Trade Office in Taipei, done in March 13rd, 2013 and interview with the Head of Investment Department, Indonesian Economic and Trade Office in Taipei, done on March 13rd, 2013

7 Ibid.
}

\section{Socio-Cultural Interests}

Indonesia's socio and cultural interest toward Taiwan mostly stem from the interactions that built by Indonesian migrant workers and Indonesian students in Taiwan. Their huge population and interaction in Taiwan also caused three different levels of interactions. On the context of socio-cultural relations, interest not only forms through people but also from the existing institutions.

Unofficial socio-cultural interactions between Indonesia and Taiwan occur through several socio-cultural activities done by Indonesian migrant workers and Indonesian students. Indonesian migrant workers through its institution called IPIT usually conduct a discussion forum to solve violation related to migrant workers. This discussion forum involves other institutions from Taiwan such as Taiwan International Workers Association. Both institutions create unofficial social interactions through their discussion forum. Furthermore, migrant workers that work as care-taker also contribute to unofficial socio-cultural interactions both for Taiwanese society and Indonesia.

In addition to Indonesian migrant workers, Indonesian students in Taiwan also build unofficial socio-cultural relations with Taiwan. These students periodically held Indonesian Cultural Festival or Exhibition in order to promote Indonesian culture to international community particularly Taiwan.

This event not only invites students from Indonesia to perform but also students and faculty member of Taiwan's university to enjoy the cultural performance. This activity creates unofficial cultural exchanges between Indonesia and Taiwan through Indonesian's dance, music and drama performance. 
The second level of interactions is semiofficial interactions. On this level, sociocultural interactions is not only built by Indonesian students but also conducted by Indonesian businessmen under their own institution. From 1990 until 2012, there have been six semi-official interactions between Indonesia and Taiwan as shown in the Table 8.

The table 8 clearly describes several semi-official exchanges between Indonesia and Taiwan in terms of socio-cultural relations. Exchanges mostly occurred due to the interactions built from Indonesian students and Indonesian businessmen.
On this context, Indonesian businessmen under ICATI not only contribute to semi-official economic exchanges but also semi-official sociocultural exchanges. The outcome of these exchanges will improve the number of Indonesian students in Taiwan, strengthen socio-cultural interactions in the future, and create mutual understanding among the society.

The last level of interactions is official socio-cultural interactions that include government to government exchanges between Indonesia and Taiwan.

Table 8 Semi-Officials Socio-Cultural Exchanges between Indonesia and Taiwan, 1990-2012

\begin{tabular}{|c|c|c|}
\hline Date & Semi-Official Exchanges & Main Aims \\
\hline 2004 & $\begin{array}{l}\text { Taiwan through its Ministry of } \\
\text { Education provide Taiwan } \\
\text { Government Scholarship for } \\
\text { Indonesian students }\end{array}$ & $\begin{array}{l}\text { To encourage outstanding international students } \\
\text { to undertake degree studies in Taiwan so as to } \\
\text { familiarize themselves with academic } \\
\text { environment in Taiwan and promote } \\
\text { communication, understanding and friendship } \\
\text { between Taiwan and countries around the } \\
\text { world }\end{array}$ \\
\hline April 2010 & $\begin{array}{lrr}\text { ICATI together with } & \text { Taiwan } \\
\text { Business Club and TETO } \\
\text { representative visited } & \text { West } \\
\text { Kalimantan, Indonesia } & \\
\end{array}$ & $\begin{array}{l}\text { In order to realize MOU sister-city between } \\
\text { Taoyuan and Singkawang, West Kalimantan }\end{array}$ \\
\hline May 2010 & $\begin{array}{l}\text { The Elite Study in Taiwan (ESIT) } \\
\text { delegation visited Indonesia }\end{array}$ & $\begin{array}{l}\text { To enhance education cooperation with } \\
\text { Indonesia }\end{array}$ \\
\hline October 2010 & $\begin{array}{l}\text { The Ministry of Education Taiwan } \\
\text { held the first Taiwan Higher } \\
\text { Education Fair in Indonesia }\end{array}$ & $\begin{array}{l}\text { To strengthen cultural and educational } \\
\text { interchange between Taiwan and Indonesia }\end{array}$ \\
\hline $\begin{array}{l}\text { September- } \\
\text { October } 2011\end{array}$ & $\begin{array}{l}\text { The second Taiwan Higher } \\
\text { Education Fair took place in Aceh, } \\
\text { Yogyakarta and Surabaya }\end{array}$ & $\begin{array}{l}\text { to facilitate Indonesian students with } \\
\text { information of scholarship and university } \\
\text { admission procedure }\end{array}$ \\
\hline October 2012 & $\begin{array}{l}\text { The third Taiwan Higher } \\
\text { Education Fair held in Surabaya } \\
\text { and Jakarta }\end{array}$ & $\begin{array}{l}\text { to facilitate Indonesian students with } \\
\text { information of scholarship and university } \\
\text { admission procedure }\end{array}$ \\
\hline
\end{tabular}

Source: Data collected randomly from reliable sources such Governmental Official Webpage and Indonesia and Taiwan Newspaper 
Under the absence of diplomatic relations, it would be difficult for Indonesia and Taiwan to conduct formal governmental exchanges; however, peopleto-people interactions contribute to the official socio-cultural interactions between the two countries.
Furthermore, the existence of institutions in Taiwan also helps the Indonesian government to have better understanding toward Taiwan. During 1990 until 2012, there have been 7 governmental exchanges between Indonesia and Taiwan on terms of socio-cultural issues. Detail exchanges sum-up in Table 9.

Table 9 Officials Socio-Cultural Exchanges between Indonesia and Taiwan, 19902012

\begin{tabular}{|c|c|c|}
\hline Date & Governmental Exchanges & Main Aims \\
\hline December 2004 & $\begin{array}{l}\text { Indonesian and Taiwan signed } \\
\text { MOU on labor importation }\end{array}$ & $\begin{array}{l}\text { To lift a ban on labor importation from } \\
\text { Indonesia that had been started since August } \\
2002 \text {. From this MOU, Indonesian migrant } \\
\text { workers could start working in Taiwan again } \\
\text { after the banned for two years }\end{array}$ \\
\hline 2010 & $\begin{array}{l}\text { The Aceh Government signed } \\
\text { MOU with Taiwan Ministry of } \\
\text { Education to provide scholarship } \\
\text { for the Aceh citizenship (Beasiswa } \\
\text { Pemerintah Aceh) }\end{array}$ & $\begin{array}{l}\text { To rebuild Aceh's government and professional } \\
\text { resources after the Tsunami in } 2004\end{array}$ \\
\hline January 2011 & $\begin{array}{l}\text { the MOU on The Recruitment, } \\
\text { Placement and Protection of } \\
\text { Indonesian Overseas Workers } \\
\text { between Indonesia and Taiwan } \\
\text { has been approved }\end{array}$ & $\begin{array}{l}\text { To renew the MOU on labor importation that } \\
\text { had been signed between Indonesia and Taiwan } \\
\text { in } 2004\end{array}$ \\
\hline May 2011 & $\begin{array}{l}\text { The Ministry of National } \\
\text { Education Indonesia and the } \\
\text { Ministry of Education Taiwan } \\
\text { signed MOU on Cooperation in } \\
\text { the Field of Higher Education }\end{array}$ & $\begin{array}{l}\text { To provide scholarship to students of related } \\
\text { universities, to facilitate the exchange program } \\
\text { in education, to encourage joint research and } \\
\text { international publication between Indonesia and } \\
\text { Taiwan. }\end{array}$ \\
\hline July 2011 & $\begin{array}{l}\text { IETO Office in Taipei set up the } \\
\text { establishment of Labor } \\
\text { Department }\end{array}$ & $\begin{array}{l}\text { To further take over the Indonesian migrant } \\
\text { workers affairs. Before 2011, the labor } \\
\text { department was under the Immigration } \\
\text { Department. However, due to the needs and } \\
\text { necessity to set up independent department, } \\
\text { Labor Department was established in July } 2011\end{array}$ \\
\hline January 2012 & $\begin{array}{l}\text { Taiwan's legislature has amended } \\
\text { an act that allowed foreign } \\
\text { workers to remain in the country } \\
\text { for only nine years at the most for } \\
\text { up to } 12 \text { years }\end{array}$ & $\begin{array}{l}\text { To give more opportunity for foreign workers to } \\
\text { stay and work longer in Taiwan }\end{array}$ \\
\hline April 2012 & $\begin{array}{l}\text { The First Taiwan-Indonesia } \\
\text { higher education summit took } \\
\text { place in Taipei }\end{array}$ & $\begin{array}{l}\text { To disseminate the MOU on the cooperation of } \\
\text { higher education which had been signed in May } \\
2011\end{array}$ \\
\hline
\end{tabular}

Source: Data collected randomly from reliable sources such Governmental Official Webpage and Indonesia and Taiwan Newspaper 
The table above shows that official socio-cultural exchanges stem after the massive interactions lead by Indonesian migrant workers and Indonesian students in Taiwan. On the context of migrant workers, Indonesia signed MOU in 2004 and 2011. In 2004, Indonesia signed MOU to overcome the problem of ban Indonesian migrant workers. Moreover, in 2011 Indonesia renewed the MOU with Taiwan's government. Furthermore in July 2011, the IETO office set up Labor Department to undertake the migrant workers affairs. Those efforts are in line with the dynamic interaction which emerged from the massive connection produced by Indonesian migrant workers in Taiwan.

The Indonesian government that adhere one-China policy will be difficult to conduct official governmental relations in terms of socio-cultural relations. However, due to the existence of Indonesia migrant workers in Taiwan, the Indonesian government is able to conduct official governmental exchanges. On this manner, the Indonesian government serves its basic function as economic and security provider for its citizen. In addition, the government also works together with institution such IPIT, APIT and PPI Taiwan to maximize the state's function as economic and security provider toward Indonesian migrant workers.

Similar case with the migrant workers, Indonesian students in Taiwan also shape the socio-cultural interests of Indonesia toward Taiwan. Indonesian government signed MOU on higher education cooperation in 2011 in order to improve the socio-cultural exchanges between two countries. Furthermore, both countries also worked to hold Indonesia and Taiwan Higher Education Summit. Those efforts conducted to strengthen socio-cultural exchanges between Indonesia and Taiwan that already well-established through the intense interactions of Indonesian students in Taiwan. Moreover, the Indonesian government representative in Taipei also works with PPI Taiwan to further discuss about the possibility of opening up the education attache in IETO in the near future (Head of Perhimpunan Pelajar Indonesia di Taiwan (PPI Taiwan) 2013). Thus, in this line, shared ideas of entering Taiwan in the purpose of study contribute to the making up institutions that eventually influence state-to-state interactions.

In sum, Indonesia economic and sociocultural interest toward Taiwan stem and constitute from the process of distribution ideas and creation of institutions which built by Indonesian businessmen, Indonesian migrant workers and Indonesian students in Taiwan. These three categories of people that serve as the promoter of ideas lead the interaction with Taiwan which eventually encourages the Indonesian government to maintain its economic and socio-cultural relations with Taiwan. In addition, people-to-people interactions resulted in three different levels of exchanges: unofficial, semi-official and official exchanges.

\section{Conclusion}

As mentioned before, the main aim of this paper is to analyze the underlying reason that caused Indonesia is able to nurture its economic and socio-cultural relations with Taiwan even though under the absence of political diplomatic relations. In order to analyze the underlying reason, this thesis employs constructivist approach that focus on the role of people-to-people interactions between Indonesia and Taiwan.

This paper argues that Indonesian people as the promoter of ideas lead the interactions with Taiwan thus made the Indonesian government maintains its economic and socio-cultural relations with Taiwan. Ideas that narrow down into 
private knowledge and socially shared knowledge influence the Indonesian businessmen, Indonesian migrant workers and Indonesian students to conduct peopleto-people interactions with Taiwan.

Moreover, these distributed ideas contribute to the making up institutions. Those institutions served as independent economic agent, independent social agent and independent cultural agent that influence the work of the structure which is the government. The distribution of ideas together with creation of institutions constitutes interest of Indonesia toward Taiwan.

Economic interest of Indonesia toward Taiwan stem from people-to-people interactions that built from Indonesian businessmen together with Taiwanese investors, meanwhile Indonesia's socio and cultural interest toward Taiwan stem from the interactions that built by Indonesian migrant workers and Indonesian students in Taiwan. During 1990 until 2012, there were both 6 semi-officials exchanges in terms of economic and socio-cultural issues.
Meanwhile, in terms of economic official exchanges, Indonesia conducted 9 contacts with Taiwan; while 7 government exchanges in terms of socio-cultural issues. These contacts occurred after intense interactions conducted by Indonesian businessmen, Indonesian migrant workers and Indonesian students.

Under the absence of diplomatic relations, Indonesian government served as economic and security provider for the activities built by Indonesian businessmen, Indonesian migrant workers and Indonesian students. It is the basic function and the obligation of the state to protect their citizen interest wherever the citizen reside or living. On the context of economic and security provider, the government facilitates people-to-people interactions through some activities such issuing visa, signing MOU that can strengthen the mutual interactions, providing better environment for economic activities, formulating regulations and other activities that categorized as the basic functions of the state. The clear picture of Indonesia and Taiwan relations shows below (Figure 7).

Figure 7 Analytical Framework on Indonesia-Taiwan Relations

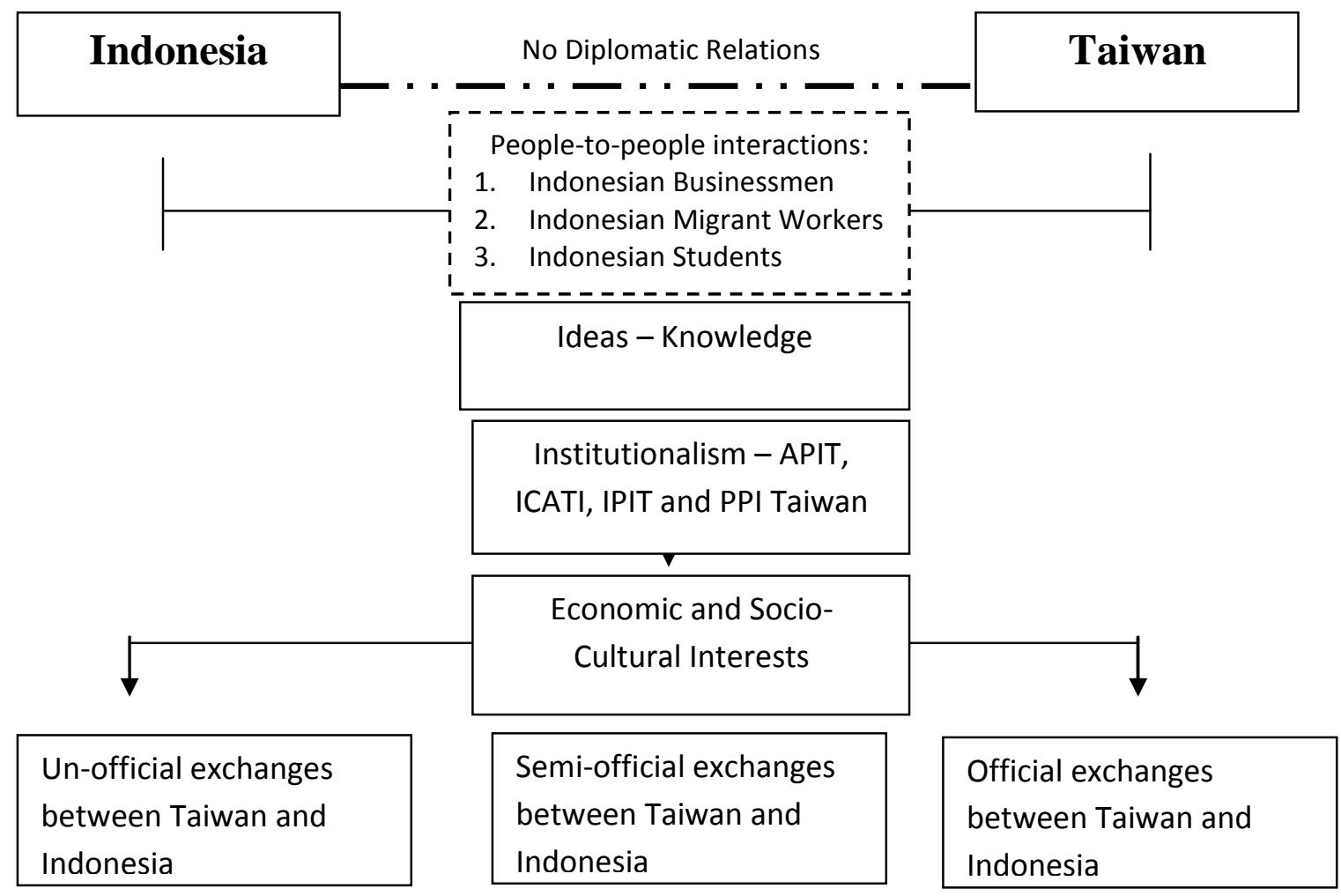


At first Indonesian and Taiwan do not have official diplomatic relations. However, people in terms of Indonesian businessmen, Indonesian migrant workers and Indonesian students keep coming to Taiwan or keep in touch with Taiwan for business, working and studying activities. These people shared their ideas about private and socially shared knowledge that caused them to come to Taiwan. Moreover, in Taiwan, these people build some institutions to further strengthen their interactions with Taiwan. Furthermore, shared ideas that contribute to making-up institutions constitute the economic and socio-cultural interests of Indonesia. The economic and socio-cultural interests define through three different levels of exchanges between Indonesian and Taiwan: unofficial exchanges, semi-official exchanges, and official exchanges. The second and third level of exchanges not only consists of economic and socio-cultural interest but also contribute to the political implications in terms of government-to-government relations. Hence, due to the Indonesian people as promoter of ideas lead the interactions with Taiwan; Indonesia is able to maintain its durable economic and sociocultural relations with Taiwan despite under the absence of diplomatic relations.

\section{About Author}

Luh Nyoman Ratih Wagiswari Kabinawa is a Junior Lecturer at Department of International Relations, Bina Nusantara University. She obtained her master degree from Institute of China and Asia-Pacific Studies, National Sun Yat-sen University, Taiwan, ROC. Her area of interest includes Taiwan's relation with Southeast Asia, ethnic Chinese in Southeast Asia, people-to-people relations, and international political economy. She can be contacted at lratih@binus.edu,

\section{References}

\section{Journal Article}

Chen, Xiangmiang. (May 1996) Taiwan Investments in China and Southeast Asia: "Go West, but Also Go South." Asian Survey, 36, 5, 447-467

Kaneko, Kenji. (2009) Foreign Migrants in Taiwan and Japan: A Comparative Analysis. Asia Journal of Global Studies, 3, 1, 22-36

Keohane, Robert O., and Joseph S. Nye. (Autumn 1987) Power and Interdependence Revisited". International Organization, 41,4

Krasner, Stephen D. (July 2001) Abiding Sovereignty. International Political Science Review, 22, 3, 229-251

$\mathrm{Ku}$, Samuel C.Y. (December 1995) The Political Economy of Taiwan's Relations with Southeast Asia: "The Southward Policy". Contemporary Southeast Asia, 7, 3, 282-297

(1998) Southeast Asia and Cross-strait Relations: The Policy of Separation of Politics and Economics. Journal of Contemporary China, 7,19, 421-442

$$
\text { (Fall 2002) The Political }
$$

Economy of Regime Transformation: Taiwan and Southeast Asia. World Affairs, $165,2,59-78$

$$
\text { (October 2009) Taiwan }
$$

and Southeast Asia since Ma Ying-jeou's Presidency. East Asia Policy, 482, 87-95

Relations with China and Taiwan: From Politics to Economics. Asian Perspective, 26,4, 227-256

$$
\text { (June 1998) Taiwan's }
$$

Diplomatic Maneuvers in the Asia-Pacific: A Perspective of Complex Interdependence. Issues and Studies, 34, 6, 80-97

Leifer, Michael. (March 2001) Taiwan and Southeast Asia: The Limits to Pragmatic Diplomacy. the China Quarterly, 165,173-185

Leong, Ho Khai. (Spring 1995) New Directions in Taiwan-Southeast Asia 
Relations: Economics, Politics, and Security. Pacific Focus, X, 1, 81-100

Lin, Chun Hung. (2010) Critical Assessment of Taiwan's Trade and Investment Relationship with ASEAN Countries in the Past, Present and Future. Miskolc Journal of International Law, 7, 1, 6182

Loveband, Anne. (2004) Positioning the Product: Indonesian Migrant Workers in Taiwan. Journal of Contemporary Asia, 34, 3, 336-348

Rich, Timothy S. (December 2009) Status for Sale: Taiwan and the Competition for Diplomatic Recognition. Issues and Studies, 45,4,159-188

Snyder, Jack. (Nov/Dec 2004) One World, Rival Theories. Foreign Policy 145

Walt, Stephen M., (Spring 1998) Testing Theories of Alliance Formation: The Case of Southwest Asia. International Organization $42,2,275-316$

(Spring 1998)

International Relations: One World, Many Theories. Foreign Policy, 110, 29-46

Wendt, Alexander. (Spring 1992) Anarchy is what States Make of it: The Social Construction of Power Politics. International Organization 46, 2

\section{Book}

Ho Khai and Hou Kok Chung, eds. (2006). Ensuring Interests: Dynamics of ChinaTaiwan Relations and Southeast Asia. Malaysia: Institute of China Studies.

Jie, Chen. (2002). Foreign Policy of the New Taiwan: Pragmatic Policy in Southeast Asia. Massachusetts: Edward Elgar Publishing Limited.

$\mathrm{Ku}$, Samuel C.Y. (2005). Taiwan's Southward Policy and Its Changing Relations with Southeast Asia, 1990-1997. Singapore: East Asian Institute, National University of Singapore

Mingst, Karen. (1996). Essential of International Relations. New York: W.W. Norton \& Company.
Wendt, Alexander. (1999). Social Theory

of International Politics. Cambridge: Cambridge University Press.

\section{Policy Paper}

Center for Political Studies (P2P) LIPI. (2011). Policy Paper: the Dynamic and Current Status of Indonesia-Taiwan Relations, Jakarta: Center for Political Studies (P2P) LIPI

\section{Website}

Antara News. News Focus: Taiwan Investment in Indonesia Improving. Retrieved on March 21 st, 2013 from $<$ http://portal.antaranews.com/en/news/793 31/news-focus-taiwan-investment-inindonesia-improving>

Bantarto Bandoro (2013, January 13 ${ }^{\text {rd }}$ ). RI Should be More Diplomatic toward Taiwan. The Jakarta Post. Retrieved from $<$ http://www.thejakartapost.com/news/2003 /01/12/ri-should-be-more-diplomatictoward-taiwan.html>

Bureau of Foreign Trade: Trade Statistics, Republic of China (Taiwan). Value of ROC Exports and Imports by Country/Product. Retrieved on January $12^{\text {nd }}$, 2013

from $<$ http://cus93.trade.gov.tw/ENGLISH/FSCE/ $>$

Central Intelligence Agency. World Factbook: Taiwan. Retrieved on March 24 ${ }^{\text {th }}$, 2013 from $<$ https://www.cia.gov/library/publications/t he-world-factbook/geos/tw.html>

Central Intelligence Agency. World Factbook: Indonesia. Retrieved on March 24 $4^{\text {th }}$, 2013

from $<$ https://www.cia.gov/library/publications/t he-world-factbook/geos/id.html>

Council of Labor Affairs, Republic of China (Taiwan). Foreign Workers in Productive Industries and Social Welfare by Industry. Retrieved on March 20 ${ }^{\text {th }}, 2013$ from $<\quad$ http://www.cla.gov.tw/cgi-

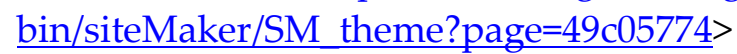


Council of Labor Affairs, Republic of China (Taiwan). Foreign Workers in Productive Industries and Social Welfare by Industry and Nationality. Retrieved on March $20^{\text {th }}, 2013$ from <http://www.cla.gov.tw/cgibin/siteMaker/SM theme?page $=49 \mathrm{c} 05774>$

Council of Labor Affairs, Republic of China (Taiwan). Foreign Workers in Productive Industries and Social Welfare by Sex. Retrieved on March 20th 2013 from $<$ http://www.cla.gov.tw/cgi-

bin/siteMaker/SM theme?page $=49 \mathrm{c} 05774>$

Elite Study in Taiwan (ESIT) Program Office. Southeast Asian Scholarship. Retrieved on March $18^{\text {th }}, 2013$ from $<$ http://www.esit.org.tw/scholarship.php?la ng=eng\&type $=4>$

Hong, Jon-Chao; Yang, Yi-Chiang; Chen, Jin-Fu; Yang, Tin-Ya,. Foreign Workers in Taiwan. National Taiwan Normal University, Retrieved on March 24 ${ }^{\text {th }}, 2013$ from

$<$ http://www.jil.go.jp/foreign/countryreport/ 2005_1107/taiwan_e.pdf>

Ikatan Citra Alumni Taiwan seIndonesia (ICATI). ICATI: Profil. Retrieved on May $10^{\text {th }}, 2013$ from $<$ http://icati.org/profil.asp $>$

Ikatan Citra Alumni Taiwan seIndonesia (ICATI). Lawatan Ketua Umum, Ibu Rini Lestari, ke Kalbar Bersama Rombongan TETO \& Taiwan Business Club. Retrieved on May 12nd, 2013 from $<$ http://icati.org/detilkegiatan.asp?id=5>

Indonesian Economic and Trade Office to Taipei. Joint Working Group (JWG) Meeting of Labor between Indonesia and Taiwan on 29th April 2011 at The Grand Hotel Taipei. Retrieved on February 20 $0^{\text {th }}, 2013$ from < http://www.kdeitaipei.org/eg/index.php?op tion=com content\&view=article\&id=134:joi nt-working-group-jwg-meeting-of-laborbetween-indonesia-and-taiwan-on-29thapril-2011-at-the-grand-hoteltaipei\&catid=41:news-and-event $>$

Investment Commission, MOEA, ROC. Statistics on Approved Outward Investment by
Year and Area. Retrieved on January $10^{\text {th }}$, 2013 from< http://www.moeaic.gov.tw/>

International Office Institute Teknologi Sepuluh November. Meet Taiwan NTUST and Find Your Overseas Study Opportunities. Retrieved on April 5 $5^{\text {th }}, 2013$ from $<\underline{\text { http://io.its.ac.id/meet-taiwan-ntust-and- }}$ find-your-overseas-study-opportunities/>

Kantor Dagang dan Ekonomi Indonesia di Taipei. Penandatanganan MOU on Morotai Development Project. Retrieved on January 13rd, 2013 from <http://kdeitaipei.org/id/index.php?option=com conten t\&view=article\&id=413:penandatangananmou-on-morotai-developmentproject\&catid=34:berita\&Itemid $=55>$

Kantor Dagang dan Ekonomi Indonesia di Taipei. Daftar Tarif Pelayanan Imigrasi. Retrieved on May 19th, 2013 from $<$ http://kdeitaipei.org/id/index.php?option= com wrapper\&view $=$ wrapper\&Itemid $=58>$

Kompas. Investor Asing Ingin Beli Pulau Morotai. Retrieved on January 13rd, 2013 from

$<$ http://regional.kompas.com/read/2012/09/2 7/08495460/Investor.Asing.Ingin.Beli.Pulau. di.Morotai $>$

Ministry of Education Republic of China (Taiwan). An Introduction to Overseas Chinese School. Retrieved on March 21 $1^{\text {st }}, 2013$ from

$<$ http://140.111.1.127/ct.asp?xItem=307\& ctNode $=422 \& \mathrm{mp}=11>$

Ministry of Education Republic of China (Taiwan). Statistical Summaries. Retrieved on April 28 th $^{\text {th }} 2013$ from $<$ http://english.moe.gov.tw/ct.asp?xItem=14

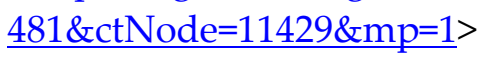

Pusat Penelitian Politik LIPI. Joint Workshop P2P LIPI and CIER TASC "The Dynamics and Current Status of IndonesiaTaiwan Relations". Retrieved on April 5 $5^{\text {th }}$, 2013 from $<$ http://www.politik.lipi.go.id/index.php/in/ kegiatan/580-joint-workshop-p2p-lipi-andcier-tasc-the-dynamics-and-current-statusof-indonesia-taiwan-relations > 